\title{
Electrochemical degradation of scarlet red dye from aqueous environment by titanium-based dimensionally stable anodes with SS electrodes
}

\author{
E. Gomathi ${ }^{1}$ B. Balraj ${ }^{2}$ K. Kumaraguru' ${ }^{1}$
}

Received: 23 November 2017 / Accepted: 27 February 2018/Published online: 12 March 2018

(C) The Korean Society for Applied Biological Chemistry 2018

\begin{abstract}
Textile effluents are toxic and carcinogenic materials that exist in the aquatic environment. In this study, the degradation efficiency of commercially available scarlet red dye investigated on TSA-SS Electro Fenton process (EFP) was reported. It is of great interest in the field of environmental engineering to remove dyes from aquatic environment. The influence of operating parameters such as $\mathrm{pH}(2-9)$, current density $\left(0.1-0.5 \mathrm{~mA} / \mathrm{cm}^{2}\right)$, concentration of dye $(0.1-0.5 \mathrm{~g} / \mathrm{L}), \mathrm{H}_{2} \mathrm{O}_{2}(0.1-0.5 \mathrm{~g} / \mathrm{L})$ concentration and $\mathrm{Fe}^{2+}$ concentration $(0.01-0.03 \mathrm{~g} / \mathrm{L})$ were analyzed by batch system. The optimum degradation conditions were determined as $\mathrm{pH}-3$, current density$0.4 \mathrm{~mA} / \mathrm{cm}^{2}$, concentration of dye $-0.4 \mathrm{~g} / \mathrm{L}, \mathrm{H}_{2} \mathrm{O}_{2}$ concentration- $0.5 \mathrm{~g} / \mathrm{L}$ and $\mathrm{Fe}^{2+}$ concentration- $0.025 \mathrm{~g} / \mathrm{L}$. These results indicated that the degradation efficiency of scarlet red dye by EFP depends on solution $\mathrm{pH}$ and Fenton reagent concentration and a low $\mathrm{pH}$ value was favorable for the dye degradation. It has been demonstrated that more than $94 \%$ dye removal was obtained at $50 \mathrm{~min}$. Electro Fenton process was also investigated by cyclic voltammetry technologies.
\end{abstract}

Keywords Electro Fenton process - Dye degradation . TSA-SS electrode

K. Kumaraguru

kumaraguruautt@gmail.com

1 Department of Petrochemical Technology, Bharathidasan Institute of Technology (BIT) Campus, Anna University, Tiruchirappalli 620024, India

2 Department of Electrical and Electronics Engineering, M. Kumarasamy College of Engineering, Karur 639113, India

\section{Introduction}

The pot ability of water is affected by various factors which include wastewater from industries. Various industries such as textiles, rubber, plastics, paper, cosmetics and tanneries use various dyeing process. They release waste water which contains dye effluents in a major proportion. Among them, textile industries generate large volume of effluents which contains organic dye effluents. Various processes were adopted to treat wastewater containing organic contaminants, particularly electrocoagulation, ultra-filtration, reverse osmosis (RO) and activated carbon adsorption. These treatment processes were not much effective to improve the quality of water with tolerable levels of effluents. To attain this objective, a treatment method is applied which entail the application of advanced oxidation process (AOP) [1, 2]. This method is recommended when wastewaters have high chemical stability, low biodegradability and this produces the complete mineralization of pollutants to $\mathrm{CO}_{2}, \mathrm{H}_{2} \mathrm{O}$ and inorganic compounds [3]. This AOP is attained when EFP is carried out. This EFP could be applied for various types of contaminants especially organic substances [4]. In EFP, $\mathrm{H}_{2} \mathrm{O}_{2}$ serves as the source of $\mathrm{OH}$ radicals. So, with increase in $\mathrm{H}_{2} \mathrm{O}_{2}$ concentration degradation takes place effectively. These hydroxyl radicals act as redox agent with high redox potential. But if $\mathrm{H}_{2} \mathrm{O}_{2}$ concentration exceeds the limit, it will affect the process by production of per hydroxyl radicals [5] as shown in Eq. (1).

$\mathrm{H}_{2} \mathrm{O}_{2}+\mathrm{OH}^{\circ} \rightarrow \mathrm{H}_{2} \mathrm{O}+\mathrm{HO}_{2}^{\circ}$

Also $\mathrm{Fe}^{2+}$ concentration helps in increase in efficiency by production of $\mathrm{OH}^{\circ}$ radicals from $\mathrm{H}_{2} \mathrm{O}_{2}$. But after a particular concentration $\mathrm{Fe}^{2+}$ ions will have scavenging effect on $\mathrm{OH}^{\circ}$ radicals [6] as shown in Eq. (2). 
$\mathrm{Fe}^{2+}+\mathrm{OH}^{\circ} \rightarrow \mathrm{Fe}^{3+}+\mathrm{OH}^{-}$

This will reduce the efficiency of the process. So an optimum of $\mathrm{Fe}^{2+}$ concentration had to be maintained for effective degradation of the solution. The $\mathrm{pH}$ was considered to be one of the important factors which help in effective degradation [7]. At higher $\mathrm{pH}$, complex formation of $\mathrm{Fe}^{2+}$ ions will take place thereby reducing the process efficiency. In this study, the influence of various parameters had studied.

\section{Materials and methods}

\section{Physicochemical properties}

In this work, commercially used dye scarlet red was purchased from Erode textile industry and the properties of scarlet red dye are given in Table 1. All chemicals like $\mathrm{FeCl}_{3}, \mathrm{H}_{2} \mathrm{O}_{2}, \mathrm{HCl}$ and $\mathrm{KCl}$ of analytical grade purchased from merck. To test the removal efficiency UV-Vis spectroscopy (Model No. 3250, Agilent Technologies) is used for determination of dye concentration. The solution $\mathrm{pH}$ was measured with (Hanna instruments) $\mathrm{pH}$ meter.

Electrolysis was performed in a 1000-ml capacity cylindrical beaker with two electrodes. Titanium-based dimensionally stable anodes (DSA) and stainless steel (SS) were used as electrodes for anode and cathode, respectively. Area of each electrode was $50 \mathrm{~cm}^{2}$ [8]. The synthetic dye solution of various concentrations was taken, and the $\mathrm{pH}$ was adjusted by adding $0.1 \mathrm{mM} \mathrm{HCl}$ solution. After that, various proportions of Fenton's reagents were added. The electrodes were partially immersed in a beaker that contains the synthetic solution $0.1 \mathrm{mM} \mathrm{KCl}$ chosen as the supporting electrolyte to maintain the current density [9]. The required electric power during the electrolysis process was provided by a laboratory DC power supply (Aplab $0.32 \mathrm{~V}, 0-10 \mathrm{~A})$. The electrolytic cell was constantly stirred with a magnetic stirrer in order to avoid the concentration gradient.

\section{Electrochemical measurements}

Cyclic voltammetry (CV) measurements were carried out using a potentiostat/galvanostat EG\&G Model 263A and a frequency response detector FRD 100 of Princeton Applied Research. The working electrode was the glassy carbon, the counter electrode was a platinum, and a reference electrode was silver electrode. All the experiments were carried out at room temperature.

\section{Results and discussion}

\section{Influence of $\mathbf{p H}$}

In this process, $\mathrm{pH}$ is an important parameter and it affects the hydroxyl radical mechanism of EFP. The $\mathrm{pH}$ was varied within the range of 2-9. The maximum degradation efficiency was obtained at $\mathrm{pH} 3$ as illustrated in Fig. 1. Therefore, acidic $\mathrm{pH}$ favors the degradation when compared to the basic $\mathrm{pH}$ levels [10]. Because when the $\mathrm{pH}$ is increased $\mathrm{Fe}^{2+}$ ions form insoluble complexes which cannot activate $\mathrm{H}_{2} \mathrm{O}_{2}$ to produce $\mathrm{OH}$ radicals. They finally precipitate as $\mathrm{Fe}(\mathrm{OH})_{3}$ which cannot act as catalyst [11]. So degradation efficiency decreases with increase in $\mathrm{pH}$. The previous results obtained [12] were well matched with the current data.

\section{Influence of $\mathrm{Fe}^{2+}$ concentration}

$\mathrm{Fe}^{2+}$ ions added as catalyst play an important role in EFP process in which degradation takes place efficiently. Figure 2 illustrates the effect of $\mathrm{Fe}^{2+}$ concentration on degradation of dye during EFP process. These ions help in the activation of $\mathrm{H}_{2} \mathrm{O}_{2}$ and in turn help in the production of $\mathrm{OH}$ radicals leading to the degradation efficiency

Table 1 Physicochemical properties of scarlet red

Chemical name
Chemical formula
Chemical structure
Molecular weight
Class
Color index




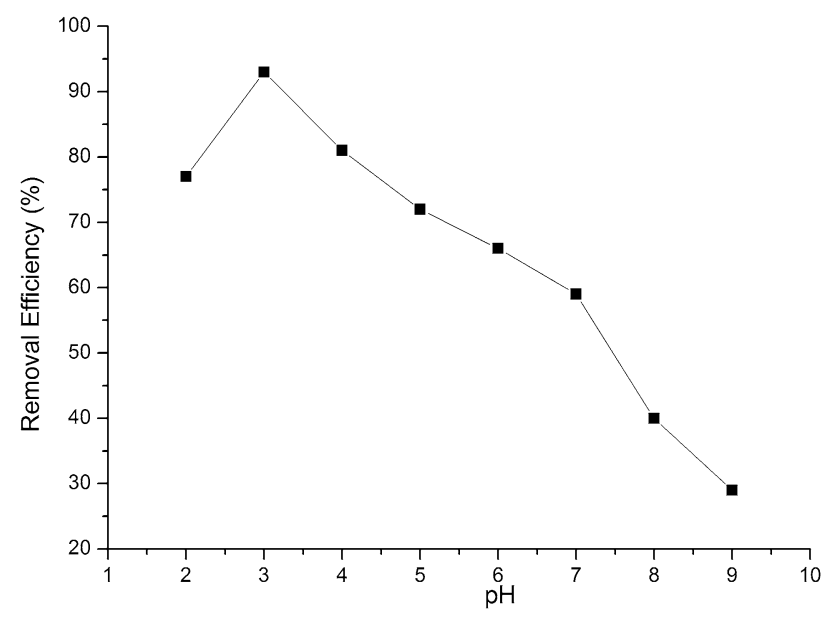

Fig. 1 Influence of $\mathrm{pH}$ on degradation of scarlet red dye in EFP processes $\quad\left(\right.$ dye $=0.1 \mathrm{~g} / \mathrm{L}, \quad \mathrm{H}_{2} \mathrm{O}_{2}=0.1 \mathrm{~g} / \mathrm{L}, \quad \mathrm{Fe}^{2+}=0.01 \mathrm{~g} / \mathrm{L}$ and $\mathrm{CD}=0.1 \mathrm{~mA} \mathrm{~cm}^{-2}$ )

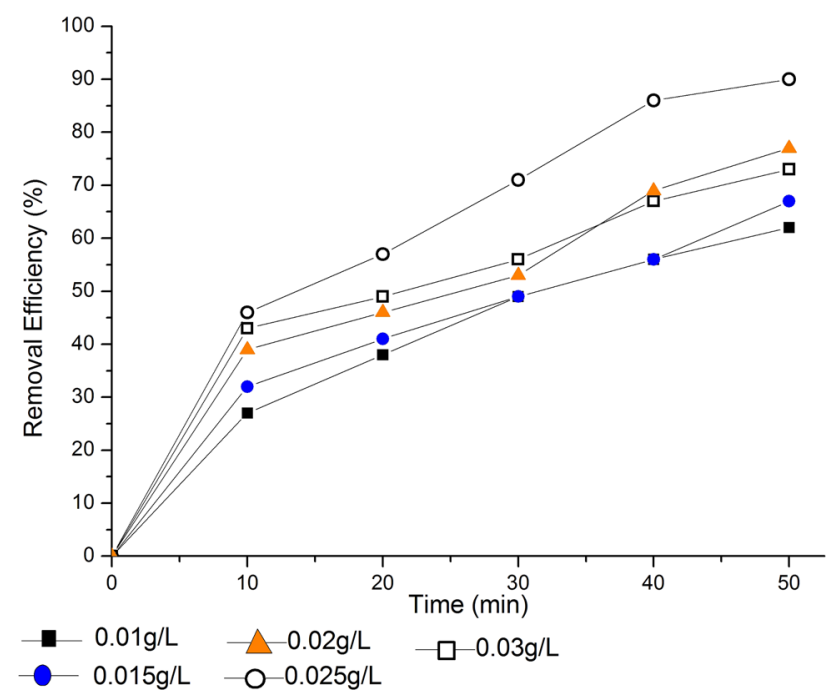

Fig. 2 Influence of $\mathrm{Fe}^{2+}$ on degradation of scarlet red dye in EFP processes $\quad\left(\right.$ dye $=0.4 \mathrm{~g} / \mathrm{L}, \quad \mathrm{H}_{2} \mathrm{O}_{2}=0.5 \mathrm{~g} / \mathrm{L}, \quad \mathrm{pH}=3 \quad$ and $\mathrm{CD}=0.4 \mathrm{~mA} \mathrm{~cm}^{-2}$ )

improvement as shown in Eq. (3) [13]. The $\mathrm{Fe}^{2+}$ concentration was varied between 0.01 and $0.03 \mathrm{~g} / \mathrm{L}$ in the interval of $0.05 \mathrm{~g} / \mathrm{L}$.

$\mathrm{Fe}^{2+}+\mathrm{H}_{2} \mathrm{O}_{2} \rightarrow \mathrm{Fe}^{3+}+\mathrm{OH}^{\circ}+\mathrm{OH}^{-}$

The optimum $\mathrm{Fe}^{2+}$ dosage with maximum degradation efficiency was found to be $0.025 \mathrm{~g} / \mathrm{L}$. After that point degradation efficiency starts to decrease. This was because of the scavenging effect of $\mathrm{Fe}^{2+}$ ions which convert $\mathrm{OH}$ radicals to $\mathrm{OH}^{-}$ions [14].

\section{Influence of $\mathrm{H}_{2} \mathrm{O}_{2}$ concentration}

$\mathrm{H}_{2} \mathrm{O}_{2}$ reagent provides the hydroxyl radicals for carrying out the mineralization mechanism that produces the sludge
[8, 15]. The concentration of hydroxyl radicals was dependent on the addition of $\mathrm{H}_{2} \mathrm{O}_{2}$ concentration [16], and it influences the decomposition of complex organic compounds by Fenton's reaction. Due to the high cost of $\mathrm{H}_{2} \mathrm{O}_{2}$ selection of an optimum $\mathrm{H}_{2} \mathrm{O}_{2}$ concentration by Fenton's reagent is important for dye degradation [17]. The degradation increases with increase in $\mathrm{H}_{2} \mathrm{O}_{2}$ concentration varied at a range of $0.1-0.5 \mathrm{~g} / \mathrm{L}$ and was the maximum efficiency obtained at $0.5 \mathrm{~g} / \mathrm{L}$ illustrated in Fig. 3. However, the increase of $\mathrm{H}_{2} \mathrm{O}_{2}$ further results in the decrease in dye removal process because surplus $\mathrm{H}_{2} \mathrm{O}_{2}$ molecules act as a scavenger of hydroxyl radical to formation of perhydroxyl radical with low oxidation potential [15].

\section{Influence of dye concentration}

Dye concentration was varied over the range of $0.1-0.5 \mathrm{~g} /$ $\mathrm{L}$. The optimum dye concentration was found to be $0.4 \mathrm{~g} / \mathrm{L}$ for which maximum degradation was obtained. Figure 4 illustrates the influence of dye concentration in EFP process at lower concentration, the lesser degradation of dye was related to the low frequency of effective collisions between molecules and surplus $\mathrm{Fe}^{2+}$ molecules causing scavenging effect [18]. But also with higher concentration of dye, efficiency of the process decreases due to the intermediate components that react with hydroxyl radicals instead of dye components [19]. Also, the reactive species produced was not enough for effective degradation of dyes at higher concentration. So when the concentration of dye increases, the amount of Fenton's reagent added to the solution had to be increased. Figure 4 illustrates the

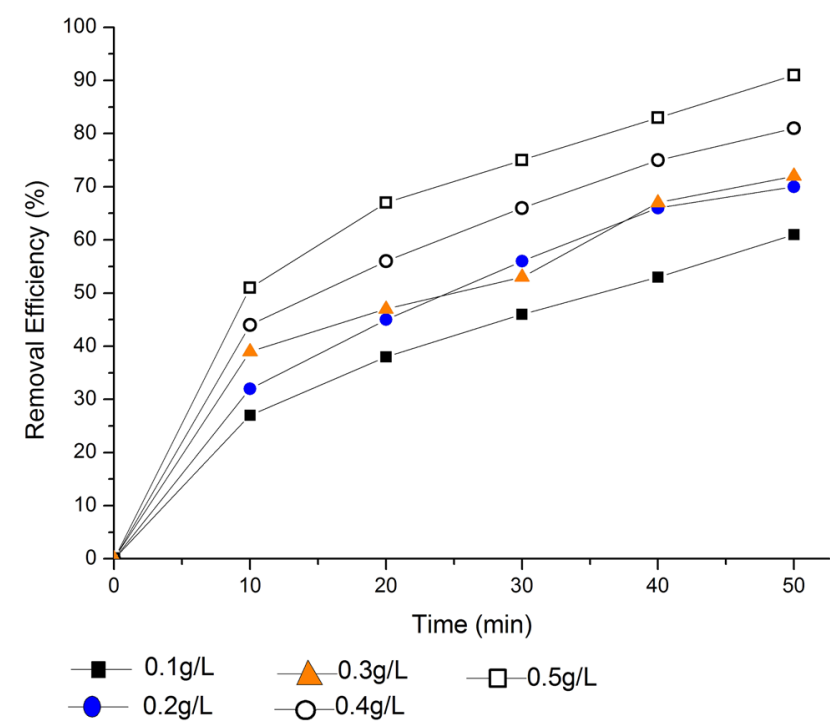

Fig. 3 Influence of $\mathrm{H}_{2} \mathrm{O}_{2}$ on degradation of scarlet red dye in EFP processes $\quad\left(\right.$ dye $=0.4 \mathrm{~g} / \mathrm{L}, \quad \mathrm{pH}=3, \quad \mathrm{Fe}^{2+}=0.025 \mathrm{~g} / \mathrm{L} \quad$ and $\mathrm{CD}=0.4 \mathrm{~mA} \mathrm{~cm}^{-2}$ ) 


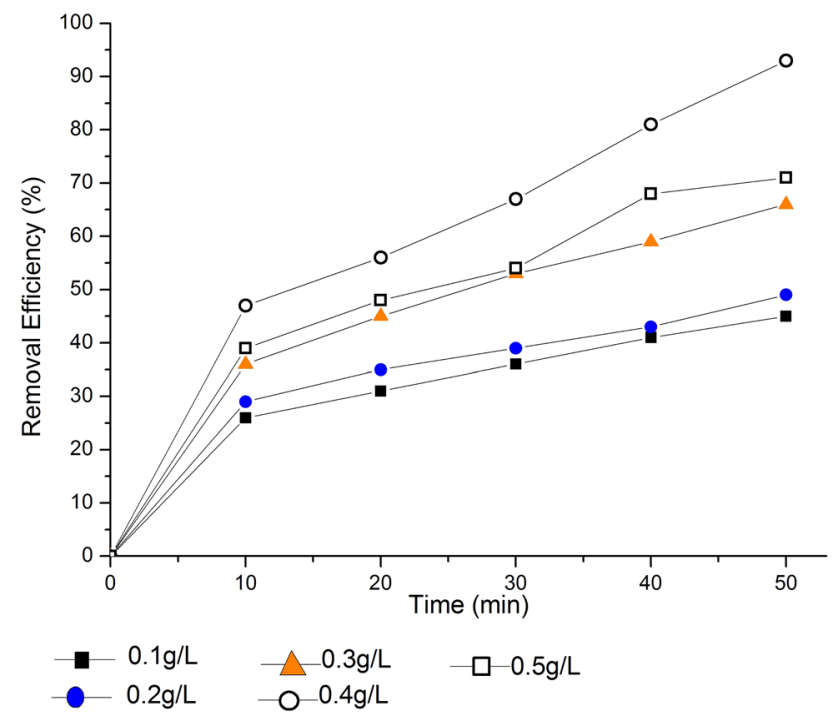

Fig. 4 Influence of dye concentration on degradation of scarlet red in EFP processes $\left(\mathrm{pH}=3, \mathrm{H}_{2} \mathrm{O}_{2}=0.5 \mathrm{~g} / \mathrm{L}, \mathrm{Fe}^{2+}=0.025 \mathrm{~g} / \mathrm{L}\right.$ and $\mathrm{CD}=0.4 \mathrm{~mA} \mathrm{~cm}^{-2}$ )

variation of degradation efficiency on the basis of dye concentration.

\section{Influence of current density}

In all oxidation mechanism of electrochemical method current density was considered to be the important parameter. The influence of current density had been examined in the range of $0.1-0.5 \mathrm{~mA} / \mathrm{cm}^{2}$ optimum of $0.4 \mathrm{~mA} / \mathrm{cm}^{2}$, and the results are illustrated in Fig. 5. The data from the graph show that there is a gradual increase in the degradation rate with increase in current. The increase

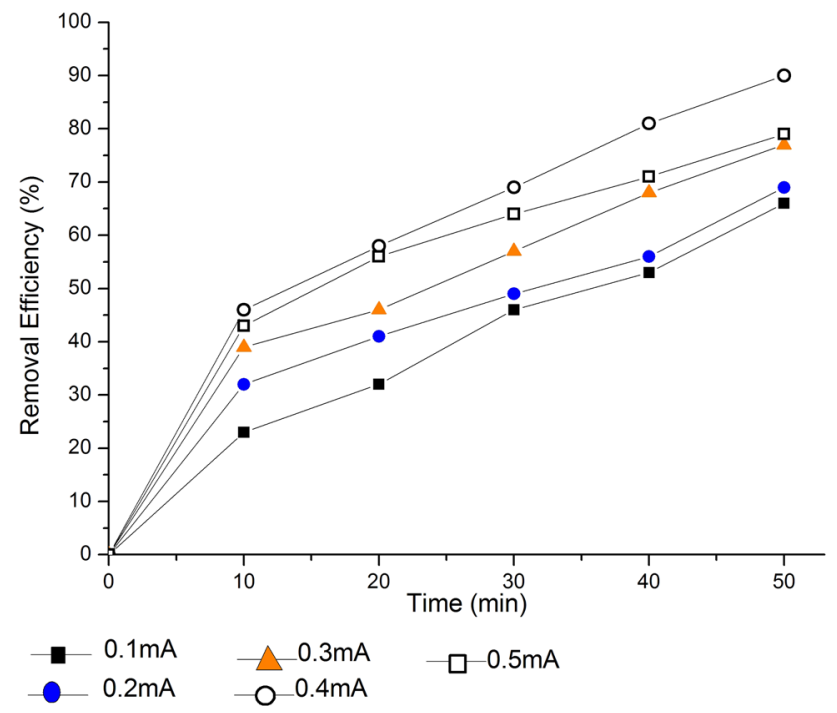

Fig. 5 Influence of current density on degradation of scarlet red dye in EFP processes $\left(\right.$ dye $=0.4 \mathrm{~g} / \mathrm{L}, \mathrm{H}_{2} \mathrm{O}_{2}=0.5 \mathrm{~g} / \mathrm{L}, \mathrm{Fe}^{2+}=0.025 \mathrm{~g} / \mathrm{L}$ and $\mathrm{pH}=3$ ) in current density enhances the oxidation power which in turn helps in the greater production of $\mathrm{H}_{2} \mathrm{O}_{2}$ and leads to the generation of more amounts of hydroxyl radicals from Fenton's reagent [20]. At higher current density, the degradation efficiency was attained almost constant due to the formation of intermediates as complexes of $\mathrm{Fe}^{2+}$ with carboxylic acids that were more difficult to destroy during electrolysis [21].

\section{Mechanism of degradation of azo dyes}

In EFP the degradation of o'scarlet red dye was investigated in acidic $\mathrm{pH}$ of $3 . \mathrm{Fe}^{2+}$ ions were used as catalyst, and $\mathrm{H}_{2} \mathrm{O}_{2}$ acts as a reagent. As the current density was intensified the degradation of dye also progressed gradually. The hydroxyl radicals produced by $\mathrm{H}_{2} \mathrm{O}_{2}$ help in this process. As the color loss becomes visible it could be explained by reaction of $\mathrm{OH}$ radicals with azo bonds ($\mathrm{N}=\mathrm{N}-$ ) [22]. They break the azo bond which causes the decolorization due to change in absorption properties. From the removal efficiency curves, we can infer that color intensity decreases as time increases during the reaction. The reaction between hydroxyl radicals and azo bonds produces hydroxylated derivatives [23]. The scarlet dye compound disappeared by producing intermediates like hydroxyl derivatives and other iron complexes.

Figure 6 illustrates the cyclic voltammetry $(\mathrm{CV})$ scan $0.4 \mathrm{~g} / \mathrm{L}$ dye solution at $\mathrm{pH} 3.0$; scan rate was $30 \mathrm{mV} / \mathrm{s}$. It was clearly visible that the Oxygen Reduction Reaction (ORR) currents at the cathode potential higher than $-0.9 \mathrm{~V}$. As the operating cathode potential of $\mathrm{H}_{2} \mathrm{O}_{2}$-producing dye solution was changed from -0.9 to $-0.7 \mathrm{~V}$ and cathode potentials appeared almost the same over the whole testing period, it was concluded that the presence of scarlet red dye had a slight impact on the ORR process

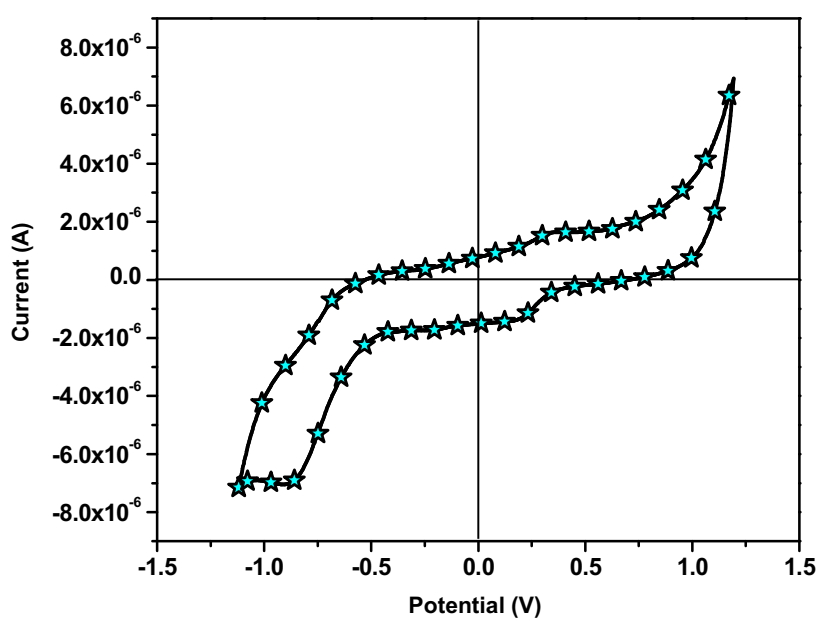

Fig. 6 Cyclic voltammetry scan of $0.4 \mathrm{~g} / \mathrm{L}$ dye solution at $\mathrm{pH} 3.0$, scan rate $30 \mathrm{mV} / \mathrm{s}$ 
occurring on the surface of the TSA-SS Electro Fenton process.

\section{Discussion}

Electro Fenton processes have been proved to be a feasible technology for the treatment of dyes from synthetic solutions. In this study, the degradation of scarlet red dye was investigated by EFP using TSA-SS electrodes. The influence of operating parameters such as $\mathrm{pH}$ (2-9), current density $\left(0.1-0.5 \mathrm{~mA} / \mathrm{cm}^{2}\right)$, concentration of dye (0.1-0.5 g/L), concentration of $\mathrm{H}_{2} \mathrm{O}_{2}(0.1-0.5 \mathrm{~g} / \mathrm{L})$ and concentration of $\mathrm{Fe}^{2+}(0.01-0.03 \mathrm{~g} / \mathrm{L})$ was analyzed in a batch system. The optimum solution $\mathrm{pH}$ for EFP for the scarlet red dye was obtained at 3 . The optimum concentration of $\mathrm{H}_{2} \mathrm{O}_{2}, \mathrm{Fe}^{2+}$ and dye concentration was $0.5,0.025$ and $0.4 \mathrm{~g} / \mathrm{L}$ with the current density of $0.4 \mathrm{~mA} / \mathrm{cm}^{2}$, respectively. At the optimal conditions, $94 \%$ of scarlet red was degraded from the solution at $50 \mathrm{~min}$. The conducted cyclic voltammetry studies confirm that, an impact was occurred over the surface of TSA-SS Electro Fenton process by the presence of scarlet red dye.

\section{References}

1. Oller I, Malato S, Sánchez-Pérez JA (2011) Combination of advanced oxidation processes and biological treatments for wastewater decontamination: a review. J Sci Total Environ 409:4141-4166

2. Matilainen A, Sillanpää M (2010) Removal of natural organic matter from drinking water by advanced oxidation processes. Chemos J 80:351-365

3. Reddy PM, Raju BR, Karuppiah J, Reddy EL, Subrahmanyam C (2013) Degradation and mineralization of methylene blue by dielectric barrier discharge non-thermal plasma reactor. Chem Eng J 217:41-47

4. Gua L, Nie JY, Zhua N, Wangc L, Yuana HP, Shoua Z (2012) Enhanced Fenton's degradation of real naphthalene dye intermediate wastewater containing 6-nitro-1-diazo-2-naphthol-4-sulfonic acid: a pilot scale study. Chem Eng J 189-190:108-116

5. Panda N, Sahoo H, Mohapatra S (2011) Decolourization of methyl orange using fenton-like mesoporous $\mathrm{Fe}_{2} \mathrm{O}_{3}-\mathrm{SiO}_{2}$ composite. J Hazard Mater 185:359-365

6. Whebi DJ, Hafez HM, El Masri MH, El Jamal MM (2010) Influence of certain inorganic ions and ligands on degradation of methyl red by Fenton's reagent. J Univ Chem Technol Metall 45(3):303-312

7. Cruz-González K, Torres-López O, García-León A, Guzmán-Mar JL, Reyes LH, Hernández-Ramírez A, Peralta-Hernández JM (2010) Determination of optimum operating parameters for Acid
Yellow 36 decolorization by electro-Fenton process using BDD cathode. Chem Eng J 160:199-206

8. Rahmani AR, Nematollahi D, Azarian G, Godini K, Berizi Z (2015) Activated sludge treatment by electro-Fenton process: parameter optimization and degradation mechanism. Korean $\mathbf{J}$ Chem Eng 32(8):1570-1577

9. Samarghandi MR, Shabanloo A, Shamsi K, Mehralipour J, Poureshgh Y (2014) Performance of Electrofenton process to remove cyanide from aquatic environments in presence of interfering humic acids. J Health 4(4):293-303

10. Panizza M, Mehmet A, Oturan (2011) Degradation of Alizarin Red by electro-Fenton process using a graphite-felt cathode. Electrochim Acta 56(20):7084-7087

11. Babuponnusami A, Muthukumar K (2012) Removal of phenol by heterogenous photo electro Fenton-like process using nano-zero valent iron. J Sep Purif Technol 98:130-135

12. Rosales E, Pazos M, Sanromán MA (2012) Advances in the electro-Fenton process for remediation of recalcitrant organic compounds. J Chem Eng Technol 35(4):609-617

13. Zhen GY, Lu XQ, Wang BY, Zhao YC, Chai XL, Niu DJ, Zhao TT (2014) Enhanced dewatering characteristics of waste activated sludge with Fenton pretreatment: effectiveness and statistical optimization. Front Environ Sci Eng 8(2):267-276

14. Zhou L, Zhongxin H, Zhang C, Bi Z, Jin T, Zhou M (2013) Electro generation of hydrogen peroxide for electro-Fenton system by oxygen reduction using chemically modified graphite felt cathode. J Sep Purif Technol 111:131-136

15. Moussavi G, Bagheri A, Khavanin A (2012) The investigation of degradation and mineralization of high concentrations of formaldehyde in an electro-Fenton process combined with the biodegradation. J Hazard Mater 237-238:147-152

16. Sevimli MF, Deliktaş E, Şahinkaya S, Güçlü D (2014) A comparative study for treatment of white liquor by different applications of Fenton process. Arab J Chem 7(6):1116-1123

17. Moussavi G, Aqanaghad M (2015) Performance evaluation of electro-Fenton process for pretreatment and biodegradability improvement of a pesticide manufacturing plant effluent. J Sustain Environ Res 25:249-254

18. Isarain-Cha'vez E, Garrido JA, Rodriguez RM, Centellas F, Arias C, Cabot PL, Brillas E (2011) Mineralization of metoprolol by electro-Fenton and photoelectro-Fenton processes. J Phys Chem 115:1234-1242

19. Azizi A, Moghaddam MRA, Maknoon R, Kowsari E (2016) Investigation of enhanced Fenton process (EFP) in color and COD removal of wastewater containing Acid Red 18 by response surface methodology: evaluation of EFP as post treatment. J Desalination Water Treat 57:14083-14092

20. Ibhadon AO, Fitzpatrick P (2013) Heterogeneous photocatalysis: recent advances and applications. J Catal. 3:189-218

21. Ghosh P, Thakur LK, Samanta AN, Ray S (2012) Electro-Fenton treatment of synthetic organic dyes: influence of operational parameters and kinetic study. Korean J Chem Eng 29(9):1203-1210

22. De Luna MD, Veciana ML, Su CC, Lu MC (2012) Acetaminophen degradation by electro-Fenton and photo electroFenton using a double cathode electrochemical cell. J Hazard Mater. 217-218:200-207

23. Xu X-R, Li X-Z (2010) Degradation of azo dye Orange G in aqueous solutions by persulfate with ferrous ion. J Sep Purif Technol 72(1):105-111 